\title{
Conceptualizing Humane Buying and Its Role in Reducing Rural Farmers' Vulnerability in a Post-Pandemic Era
}

Agu, Godswill Agu, Department of Marketing, Abia State University, Nigeria

Correspondence: godswill.agu@abiastateuniversity.edu.ng/ ORCID: https://orcid.org/00000002-7050-9430

Gazie, S. Okpara, Department of Marketing, Abia State University, Nigeria: gazie.okpara@abiastateuniversity.edu.ng

Ogwo, E. Ogwo, Department of Marketing, Abia State University, Nigeria: ogwoeogwo@gmail.com.

Chinedu, N.Ogbuji, Department of Marketing, University of Port Harcourt, Nigeria: chinedu,ogbuji@uniport.edu.ng

Aham, V. Anyanwu, Department of Marketing, Imo State University, Owerri: profchuks1234@gmail.com

\begin{abstract}
While several studies have examined the impact of the Covid-19 pandemic on smallholder rural farmers and possible efforts to scale up their livelihood and food security, the role of consumers' buying orientation in addressing farmers' vulnerability in the post-pandemic era has not been explored. The paper, therefore, aims to propose and conceptualize humane buying orientation, and further explore its role in attenuating smallholder rural farmers' vulnerability in the new normal. The qualitative design approach has been employed in two different studies. Collected data were analyzed using the SPSS 23.0 and following the interpretative phenomenological analysis. Findings validate humane buying as an altruistic orientation that will contribute to lessening the vulnerability of smallholder rural farmers in the post-pandemic era. It also shows that an enlarged-stakeholders' (government, international agencies, corporate bodies, institutions,
\end{abstract}


privileged individuals/consumers, religious organizations, etc.) effort that is rooted in morality and empathy, is required to successfully tackle the vulnerability of smallholder rural farmers, especially in developing countries such as Nigeria. The study is the first to propose, conceptualize and validate humane buying as a post-Covid-19 orientation that is capable of attenuating the vulnerability of smallholder rural farmers which has been worsened by the pandemic. The paper contributes to the understanding of emerging strategic actions required for the attainment of the United Nation's sustainable development goals - ending poverty and hunger by 2030 , and how consumers can play a key role.

\section{Graphical abstract}

\section{Existing condition of} smallholder rural farmers in developing countries Humane buying is absent. Thus, vulnerability is high and increasing.

With the adoption of humane buying, vulnerability is low and reducing.

An enlarged stakeholders' approach that is rooted in humane orientation (e.g., empathy and morality) will result in eradication of vulnerability, and increasing well-being of farmers and growth of the agricultural sector.
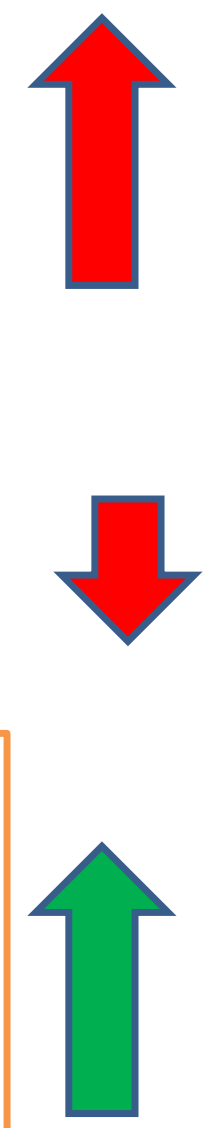
Keywords: Covid-19 pandemic; Smallholder rural farmers' vulnerability, Humane buying; Nigeria, sustainable development goals.

\section{Introduction}

In late 2019, the world was hit with a deadly disease which was later described as a pandemic on March 11, 2020 by the World Health Organization (WHO). Covid-19 pandemic, as it is called (WHO, 2020), ushered in the deepest recession since the Second World War, with the largest fraction of economies experiencing declines in per capita output since 1870 (The World Bank, 2020). The pandemic unleashed a health and economic crisis, unprecedented in scope and magnitude, with lockdowns and border closures paralyzing economic activity and laying off millions of workers globally (United Nations Report, 2020). Besides, global, regional, national, state, local, and individual family economies contrasted drastically, thus reducing general standard of living and wellbeing (Agu et al., 2021).

Nigeria, like most developing countries, received a massive negative knock of the pandemic (see Kazeem, 2020; Ozali, 2020), and this makes millions of the citizens vulnerable to falling back into deep poverty (The World Bank IBRD-IDA, 2021). According to Ozali (2020), the Covid19 outbreak not only led to a fall in the demand for oil products but also stopped economic activities from taking place when social distancing policies were enforced. Kazeem (2020) disclosed that Nigeria's economy contracted by $6.1 \%$ year on year in the second quarter of 2020 and $27 \%$ of Nigeria's labor force (over 21 million Nigerians) are unemployed as a result of the pandemic. However, a cheering recent forecast by The World Bank (2021) indicates that the global economy is poised to stage its most robust post-recession recovery, but that rebound will be uneven across countries, as major economies look set to register strong growth while many developing economies lag. This represents an official take-off into the post-pandemic era. 
While many sectors of the Nigerian economy are gradually rebounding with promising future forecasts, the agricultural sector seems to be lagging, and this has far-reaching negative implications on food security and people's livelihood (Food and Agricultural Organization, 2021; Obayelu et al, 2021). Smallholder rural farmers constitute a greater proportion of the agribusiness primary chain in Nigeria (Fidelugwuowo, 2021), and rural economies are particularly vulnerable to economic shocks due to their less diversified economic base and greater dependence on tradable activities, which tend to suffer during economic shocks (OECD, 2021). Corroborating these is the International Labour Organization, ILO (2020), which notes that smallholder farmers are among the marginalized population, and the hardest hit by the Covid-19 pandemic.

Given these facts, a joint statement by ILO, FAO, IFAD, and WHO which was published by ILO (2020:3) read thus:

"Now is the best time for global solidarity and support, especially with the most vulnerable in our societies, particularly in emerging and developing world. Only together can we overcome the intertwined health and social and economic impacts of the pandemic and prevent its escalation into a protracted humanitarian food security catastrophe, with the potential loss of already achieved development gains."

Indeed, several humanitarian efforts have been deployed by various international and national agencies such as the International Monetary Fund (IMF), the United Nations, IFAD, OECD, Economic Community of West African States (ECOWAS) etc., government at various levels, as well as corporate organizations, foundations, and individuals to alleviate the Covid-19-induced challenges. However, the manner with which the support packages (palliatives) are distributed, and the effectiveness of the process (Ufua et al., 2021) remain doubtful. In some extreme cases, palliatives were hijacked by politicians and other strong power influence individuals, denying the vulnerable population access to their share (Eranga, 2020).

In view of the sensitive nature of the agricultural sector to the livelihood of the populace, the lingering challenges posed by the Covid-19 pandemic on agribusiness, especially smallholder 
rural farmer, and the failure of most government palliatives to reach the vulnerable real farmers, this paper argues from a marketing perspective, that consumers can lead the expected positive change to ensure food security and wellbeing of the farmers. Leveraging the novel concept of humane entrepreneurship (Kim et al., 2018; Parente, 2020), the paper conceptualizes humane buying, and explores its role in helping the smallholder rural farmers to sustain livelihood and to ensure food security in the post-Covid-19 era. This has implication on the achievement of the United Nations, UN (2015) sustainable development goals (SDGs), especially SDGs one and two which aim to aim poverty and hunger by 2030 .

A review of the literature indicates that several studies have examined the impact of the Covid19 pandemic on smallholder rural farmers (e.g., Nchanji \& Lutoma 2021; Obayelu et al., 2021; Middendorf, 2021), and possible efforts to scale-up farmers' livelihood and food security (IFAD, 2020; OECD, 2020; ILO, 2020). However, no study explores the role of consumers' helping behaviour (Wilson, 1978), especially altruism, in the form of humane buying in achieving food security and farmers' motivation. According to Agu et al. (2021), consumers have a great deal of power in their pockets, and can use their purchase decision/behaviour to support or frustrate an organization. Unlike consumption boycott that emphasizes the withdrawal of purchase/support from organizations perceived to be bad (Cruz, 2017; King, 2011), humane buying is a positive form of mindful purchase that supports microbusinesses or individuals perceived to be vulnerable. It also differs from cause-related marketing which is a promotional activity of an organization in which a societal or charitable cause is endorsed commonly together with its products and services as a bundle or tie-in (Beise-Zee, 2013), and aims to benefit a third party (e.g., charity homes) other than the business organization in a transaction (Partouche et al., 2020; Ferraris et al., 2020). Humane buying aims to support a business organization directly through the purchase behaviour of the consumer, and recent research indicates that Covid-19 shock has created a new or revived a behavioural understanding of buying, as consumers demonstrate a shift towards conscious consumption (Mehta et al., 2020).

Therefore, the objective of this study is to propose and conceptualize humane buying, and to examine its role in attenuating smallholder rural farmers' vulnerability, and ensure their wellbeing and food security, in the post-Covid-19 pandemic era. 


\section{Literature Review and Theoretical Underpinning}

\subsection{Humane Buying and Relevant theories}

Humane buying is a purchase orientation that is anchored on three known theories ethical/mindful consumption, sustainability, and helping behaviour. It is conceived from an insight drawn from the recent theory of humane entrepreneurship. Humane entrepreneurship concept originated from the work of Kim et al. (2018) which defines it as a virtuous and sustainable integration of entrepreneurship, leadership, and human resource management, in which successful implementation leads to a beneficial increase in wealth and quality job creation, perpetuated in a continuous cycle. In a broad sense, it can be viewed as a strategic entrepreneurial posture that enhances social responsibility either internally to the organization's boundaries or externally to the organization's boundaries (Parente, 2020). Humane entrepreneurship focuses on people, but also has a tone of ethics and morality built in (Laplume, 2020; Parente, 2020). Specifically, humane entrepreneurship is a new model of entrepreneurship in which the attention that firms have traditionally paid to business is integrated with care for the following: firm members, the planet, and society at large (Parente, 2021).

Humane buying on the other hand, is a buying philosophy or behaviour that seeks to support, comfort, help, empower, and encourage vulnerable microbusinesses to survive and remain in business. It is an empathic and conscientious buying orientation that persuades consumers to use their purchase actions to support the downtrodden, vulnerable micro-entrepreneurs (e.g., smallholder rural farmers in developing countries) in an exchange relationship as against the usual practice of leveraging the entrepreneurs' vulnerable condition to exploit them. Unlike humane entrepreneurship, humane buying is an act in which the buyer demonstrates care and concern for the wellbeing of the vulnerable seller by engaging in actions that support them to survive. Therefore, the buyers' traditional attention to satisfaction in the exchange process is integrated with care for the wellbeing of the vulnerable seller. 
As an aspect of ethical consumption, humane buying advocates conscious purchasing and based on a particular ethical or social issue (Ethical Consumerism Report, 2011), and also implies a variety of consumption choices pertaining to environmental issues and (corporate) social responsibility (Sudbury-Riley \& Kohlbacher, 2016).Specifically, ethical consumption (trade or shopping) invites consumers to take moral responsibility or co-responsibility for consequences of buying behaviour, that is, how other people, animals and other natural environments directly or indirectly are affected (Brinkmann, 2004). Inherent in these definitions is the fact that ethical consumption is rooted in morality - subjective value judgment, usually in the interpersonal context of whether an action is right or wrong (Chin, 1989). Likewise, humane buying seeks to enthrone morality in dealing with a vulnerable, marginalized entrepreneur, by at least, reducing their exploitation by the buyer, and thus improving their wellbeing.

Also, humane buying anchors on the helping behaviour theory with emphasis on altruism. Altruism as an act of helping has been defined in various ways. First, it is a behaviour carried out to benefit another without anticipation of rewards from external sources (Macaulay \& Berkowitz, 1970). From the social perspective, Rushton (1982) sees it as social behaviour carried out to achieve positive outcome for another rather than for self. in line with Ger's (1997) humane consumption orientation that aims to enable the enhancing potential of goods and move the society toward well-being, humane buying focuses on helping the vulnerable microentrepreneurs to scale-up, and thus enhancing their well-being. It tends to be more altruistic, since this act of helping seeks another person's benefit as an ultimate goal (Bateson et al., 2003).

Again, the humane buying concept is an agent of sustainable development - development that meets the needs of the present without compromising the ability of future generations to meet their own needs (United Nations, 2020). To actualize this, the UN member states in 2015 signed into the 17 sustainable development goals (SDGs), which aim to end poverty, protect the planet and ensure that all people enjoy peace and prosperity by 2030 (UNDP, 2020). Looking at the SDGs, goals one and two are within the focus of humane buying. SDGs one and two aim to end poverty and hunger by 2030 (UN, 2015). Likewise, humane buying is an act of compassionate buying that aims to support the vulnerable to survive. Survival here implies "being sure of good living". Specifically, SDG 1 targets 1, 2 and 4 read thus: 
- By 2030, eradicate extreme poverty for all people everywhere, currently measured as people living on less than $\$ 1.25$ a day.

- By 2030, reduce at least by half the proportion of men, women and children of all ages living in poverty in all its dimensions according to national definitions.

- By 2030, build the resilience of the poor and those in vulnerable situations and reduce their exposure and vulnerability to climate-related extreme events and other economic, social and environmental shocks and disasters.

While SDG 2 targets 1,3 and 4 state read:

- By 2030, end hunger and ensure access by all people, in particular the poor and people in vulnerable situations, including infants, to safe, nutritious and sufficient food all year round.

- By 2030, double the agricultural productivity and incomes of small-scale food producers, in particular women, indigenous peoples, family farmers, pastoralists and fishers, including through secure and equal access to land, other productive resources and inputs, knowledge, financial services, markets and opportunities for value addition and non-farm employment.

- By 2030, ensure sustainable food production systems and implement resilient agricultural practices that increase productivity and production, that help maintain ecosystems, that strengthen capacity for adaptation to climate change, extreme weather, drought, flooding and other disasters and that progressively improve land and soil quality

These targets are within the focus of humane buying. Furthermore, research has confirmed that sustainable actions are influenced by morality (see Sonntag \& Spiller, 2018), the bedrock of humane actions.

\subsection{Covid-19 Pandemic, Smallholder Rural Farmer Vulnerability and Humane Buying}


Although humane buying is an emerging conceptualization, and the Covid-19 pandemic a new phenomenon, there have however, been efforts by scholars to investigate how environmental shocks affect smallholder farmers. Some studies also explored the impact of the novel Covid-19 pandemic on farmers and food security. For instance, a recent study involving 872 smallholder farmers in 14 regions of Senegal by Middendorf et al. (2021) examined the perceptions of the potential impacts of Covid-19 on agricultural systems and social well-being of the farmers, with a view to exposing the potential vulnerabilities and resilience in the targeted farming systems. The study reports that the majority of respondents expressed concern that Covid-19 would make it more difficult to get enough food on a regular basis for their household, concerns related to access to input, ability to farm, ability to sell, ability to hire labour, and reduction of yields.

Similarly, Bright et al. (2021) assessed the impact of Covid-19 pandemic on agricultural extension and food supply as well as the effectiveness of the suggested coping strategies in Zimbabwe. The study involved 100 agriculture extension officers who were reached through phone interview and structured questionnaire. Their findings indicate that agricultural extension and food supply were grossly affected by the pandemic as farmers lost their agricultural produce and investment. Besides, Obayelu et al. (2021) investigated the immediate and potential longterm effects of Covid-19 outbreak. The study, among others reports that food demand and supply shocks caused by Covid-19 outbreak affect agriculture, food and dietary intake negatively through Covid-19 policies, and that food access was compromised with the accumulation of unsold fresh produce by the smallholder farmers. In a study that involved Turkish farm enterprises, Cerher et al. (2021) examined the level of anxiety among farmers during the Covid-19 outbreak, and found that it was high.

The study of Nchanji and Lutoma (2020) which covered nine countries in Central, Eastern, and Southern Africa, aimed to understand the immediate impact of Covid-19 on production, distribution and consumption of common beans, and possible food security implications. They found that the production and distribution challenges negatively impacted on frequency and patterns of food consumption in households in Africa, leading to a greater risk to food security and poverty in the region. A pre-Covid-19 pandemic study by Agu et al. (2017) explored rural 
farmers' vulnerability in produce price negotiation and possible solutions. The study found that buyers' negative perception of the monetary value of produce and unavailability of regular, known buyers are the highest causes of vulnerability in produce pricing. The study recommended stakeholders' approach towards tackling the challenges of farmers to ensure food security. Specifically, the study advocates for a "relationship form of exchange system, where all the parties will seek to promote the well-being of one another." This implies adopting a humane approach in the exchange process.

Generally, empirical evidence suggests that the Covid-19 outbreak has affected the smallholder farmers negatively, thereby increasing their level of vulnerability (Middendorf et al., 2021; Nchanji \& Lutoma, 2021; Parwada, 2020). Scholars also recommend pragmatic approaches to reducing the challenges faced by farmers to improve their wellbeing and ensure food security (Agu et al., 2017; Bright et al., 2021). This study thus, seeks to examine the strength of humane buying in this direction.

\section{Research Methodology}

\subsection{Study Settings}

The present research involves two different studies and settings. The first study was experimental in nature and involves smallholder rural farmers in the five South-Eastern States of Nigeria Abia, Anambra, Ebonyi, Enugu, and Imo. The South-East Nigeria is known for the production of arable crops such as cassava, yam, maize, vegetables; permanent crops such as cocoa, kolanut, oil palm, rubber, cashew, banana/plantain and citrus, and livestock (Ndaeyo et al., 2000). The experiment applied the humane buying concept, observed the reactions of the smallholder farmers, and followed with a face-to-face interview.

The second study was a survey via email and phone interview of marketing professors across Nigeria. Marketing professors are relevant experts whose opinions are inevitable in validating the efficacy of the new concept - humane buying. Besides, they are relatively capable to practice the concept, being economically more stable to do so than other cadres of the teaching 
profession. The marketing profession in Nigeria is still emerging, with few professors in the university system (see National Universities Commission, NUC, 2017).

\subsection{Study Design}

The research used mixed qualitative research methodologies. The qualitative data were gathered through natural, real life experimentation/observation and expert interview. Experimental design is one of several forms of scientific inquiry employed to identify the cause-and-effect relation between two or more variables and to assess the magnitude of the effect(s) produced (Lavrakas, 2008). Furthermore, experts' opinion is viewed as adequate method for concept validation (Lofkwowitz \& Gebbia, 1997). The mixed approach will enable triangulation, which ensures validity and credibility of the data by cross verification (Honorene, 2017).

\subsection{Target Population}

The study targeted a population of smallholder farmers in Southeast Nigeria and professors of marketing across the country. There was incomplete data on the population of smallholder farmers in the zone as well as incomplete data on the population of marketing professors on the NUC (2017) website.

\subsection{Sampling procedure}

Multistage and purposive sampling techniques were adopted for the first and second studies respectively.

In the first study, we listed local government areas (LGAs) in the five states that are located in rural areas. Next, we identified 10 LGAs (two for each state) that are within close proximity to Abia State University, Uturu where our research secretariat was located. Thereafter, one community that harbours a known local market where farmers sell their produce was selected for each LGA. For each community, 3 farmers who were found 
conveying their crop to the markets were randomly selected for the experiment at different entry points of the markets after due permission was obtained by the market leaders. Because these markets (traditional Nkwo, Eke, Orie, and Afor) are rotatory in nature (observed after four or eight days), large number of farmers usually trade their produce on any market day. Thus, a total of 30 farmers were involved.

In the second study, the list and contacts of marketing professors in Nigerian public universities were generated from the NUC (2017) directory of full professors in Nigeria. Given the observed incomplete data on the directory, personal contacts were made across universities that have Department of Marketing. Besides, associate professors (Readers) who are not in the NUC list of full professors, but recognized in the professorial cadre of the NUC (2017) staff mix, were included in this study. In all, a total of 27 marketing professors were contacted via email, whatsapp and phone call. However, only 19 (70.37\%) participated.

Generally, a total of 49 (30 rural farmers and 19 marketing professors) participated in the two studies. The field experiment and all interviews lasted for fifteen weeks spanning between May to August, 2021. This study was approved by the Research, Publications and Ethics Directorate of Abia State University, Uturu, Nigeria, and the Research Ethics Unit of the Faculty of Economics and Management Sciences of the University. Again, for the first study, the consent of intended participants was sought orally and face-to-face. Thus, participation is a decision made by the smallholder rural farmers, and not a random assignment of the researchers (Gansonre, 2021). For the second study, we first sent emails, text messages, and whatsapp texts soliciting for the consent of the professors to participate in the interview and to state their preferred mode and time (Fritz \& Vandermause, 2017; Hunter et al., 2012). Participants were informed that participating in the study was voluntary (Agu, 2020), and were also assured that all information would be treated confidentially (Biotchi et al., 2021; Maricaci et al., 2021). 


\subsection{Data collection methods}

For the first study, ten trained graduate students of the Department of Marketing, Abia State University, Uturu were used to generate the data as part of their seminar paper on MKT 801 (Marketing of Primary Products) for a course credit. Each student covered one LGA. First, the research assistants approached the farmers in disguise as buyers. After the traditional haggling system, the "buyer" paid the farmer/seller double the agreed price and observed their reaction. At this point, the "buyer" introduced him/herself and sought the farmer's consent to be interviewed and for recording of the conversation (Boitchi et al., 2021). The interviews were conducted under strict adherence to the Covid-19 protocol. The interviews were conducted in Igbo vernacular and Pidgin English. The face-to-face interview was adopted following the interpretative phenomenological analysis (IPA) system. IPA is a qualitative approach which aims to provide detailed examinations of personal lived experience (Smith \& Osborn, 2015; Omisore, 2019).

Again, for the second study, we first sent text massages to the identified professors seeking their permission to participate in a research interview. Phone call, email, and whatsapp options were presented, and the professors were asked to identify the one that would be suitable for them. For those that chose the phone call option, they were also asked to indicate the day and time that would be appropriate for them. Phone call interviews lasted between 25-30 minutes. The interview was conducted in English language.

\subsection{Data analysis}

Demographic data were uploaded in SPSS version 23, and simple percentages generated. Thereafter, the qualitative interview data analysis followed the four-stage approach (Evans, 2017) - selection of the unit of analysis (whole interviews/observation); determination of meanings by coding and thematic analysis; extracting key themes by condensing generated phrases; and interpretation of themes. Quotes were used to present key findings.

\section{Results and Discussions}


Table 1: Demographic Characteristics of Participants

\begin{tabular}{|c|c|c|c|c|}
\hline Variable & Farmers & Percentage & Professors & Percentage \\
\hline \multicolumn{5}{|l|}{ Gender: } \\
\hline Male & 13 & 43.33 & 15 & 78.94 \\
\hline Female & 17 & 56.67 & 4 & 21.05 \\
\hline \multicolumn{5}{|l|}{ Marital Status: } \\
\hline Married & 18 & 60.00 & 18 & 94.74 \\
\hline Single & 4 & 13.33 & 0 & 5.26 \\
\hline Others & 8 & 26.67 & 1 & \\
\hline \multicolumn{5}{|l|}{ Religion: } \\
\hline Christianity & 28 & 93.33 & 17 & 89.47 \\
\hline Islam & 0 & 0.00 & 2 & 10.53 \\
\hline Traditional & 2 & 6.67 & - & 0.00 \\
\hline \multicolumn{5}{|l|}{ Age bracket: } \\
\hline Below 50 years & 12 & 40.00 & 4 & 21.05 \\
\hline Above 50 years & 18 & 60.00 & 15 & 78.95 \\
\hline \multicolumn{5}{|l|}{ Highest } \\
\hline \multicolumn{5}{|l|}{ Education: } \\
\hline None & 6 & 20.00 & 0 & 0.00 \\
\hline Primary & 13 & 43.33 & 0 & 0.00 \\
\hline Secondary & 11 & 36.67 & 0 & 0.00 \\
\hline Tertiary & 0 & 0.00 & 19 & 100.00 \\
\hline
\end{tabular}

Source: Researchers' Desk (2021).

\subsection{Analysis of Farmers' Responses}

First results of the experiments through observation showed that all the 30 farmers were highly excited and deeply appreciative of the humane gesture. Some expressed their joy in form of 
praise, dance and prayers (ofor: traditional prayer) to the researchers. They also disclosed that the additions will assist them in meeting family challenges and in their agribusiness. When asked whether they had experienced this kind of gesture before, only 6 (20\%) said yes. All also disclosed that they were unable to access the Covid-19 palliatives by the government. They also disclosed that the Covid-19 had far-reaching adverse effect on their household. A participant, a processed cassava farmer/seller said "For some days we had no food to eat, and nothing to rely on from the farm," (Female, below 50 years). Another respondent said, "We were forced to be eating our farm produce because of market closure," (Male, above 50 years).

The farmers identified insecurity, high cost of farm input (mainly fertilizer and labour), poor road network, family challenges, poor sales revenue caused by produce glut, high cost of transportation, and erosion threats as challenges they face. These support the research of Agu et al. (2017).

\subsection{Analysis of Marketing Professors' Responses}

All the participants disclosed that they do buy (or have bought) agricultural produce directly from the rural farmers (see Table 3). 17 (89.47\%) of the professors have supported the rural farmers by paying more than the asking price of the product. One of the participants said:

"I have in pre-Covid times. In Hausa it is sometimes referred to as "lada" which is like a tip or gratuity," (Male, above 50 years).

Another participant said "I left my balance since she didn't have it handy," (Male, above 50 years).

Again, one of the participants who said he had not paid more than an agreed price with a farmer/seller noted: "But I do give gifts to low income rural farmers of my acquaintance outside of the commercial interface," (Male, above 50 years).

On whether participants will consider to pay more to enable the vulnerable farmers survive the challenges of the Covid-19 pandemic, 18 (94.74\%) were on the affirmative. Notable responses include: 
"If he's needy, yes," (Female, above 50 years).

"Yes, I may consider to pay more to help the farmer survive," (Male, above 50 years).

"It always comes naturally to reward any hardworking farmer - so yes I would," Male, above 50 years).

“....Gifts to low income earners or farmers are a fact of the foundation of my faith." Male, above 50 years).

The analysis indicates that marketing professors engage in humane buying, and also engage in other social support activities to help vulnerable smallholder rural farmers to survive.

Majority of the participants agreed that the Covid-19 pandemic must have affected an average smallholder rural farmer adversely. According to a participant, "With the lockdowns and poor case reporting in the country, the farmers would definitely be hard hit as travelling to the market from the farm would be further hindered," (Male, above 50 years). Another respondent said "the COVID-19 pandemic affected farmers negatively especially the rural farmers. There were restrictions in movement and by that event farmers were not able to travel to nearby markets. That is to say they were restricted to sell their wares in the nearby markets at whatever price that was offered. On the other hand what was sent to the townships markets through any means by the rural farmers were in some cases little above known prices, "(Male, above 50 years). " Markets and movements were restricted. Purchases were house-based," (Male, above 50 years) was another response from a different participant. These assertions are in alignment with extant studies (Middendorf et al., 2021; Nchanji \& Lutoma, 2021; Parwada, 2020; Bright et al., 2021; Obayelu et al., 2021), and also corroborate the findings from in study one (farmers expressions).However, one participant had different view. According to him "The rural farmers I encountered appeared ready to reap optimally from the Covid- induced scarcity of many farm products. But were also aware that many buyers were experiencing declining or low income," (Male, above 50 years). In addition, a female participant said "My experience was before the pandemic. Now, most farmers lose their crops to herders and their cows. Fear of kidnapping and raping out there in the fields cause prices of commodities for those who brave going to farm has risen sharply. Consequently, most farmers have lost appreciable land and produce and are poor." This strengthens the assertion of Agu et al. (2017). 
On the role of humane buying orientation in alleviating smallholder rural farmers suffering, majority of the participants agreed that it will be of help to the farmers but may not have significant impact on their livelihood. Notable quotes on this include: "Yes, but rather tangentially as the extras are not regular," (Female, below 50 years). "Yes. It should alleviate farmers' post-Covid distortions, by injecting some social capital into their business<" (Male, above 50 years). "Yes. But they need more," (Female, above 50 years). "What can sustainably help the farmer, is assistance in his farming processes that will bring about higher yield per acreage, as well as better storage/ preservation of produce. All things being equal, these should produce higher income," (Male, above 50 years).

Few others believed the humane orientation will not make any impact. For instance, a female participant said, "Not really. How much more can the buyer give to make a meaningful difference? Also, people buy from real farmers for to buy at low prices and these are mostly traders." Another male respondent said, "NO. The government and commodity boards need to come in for stability of income to the rural farmers because small payments like this cannot go far in alleviating the plight of the rural farmer in long-run." Again a respondent, (Male, above 50 years) replied, "Tipping rural farmers is not enough. Education and training are key. These farmers also need market access and up-to-date farming techniques including storage facilities."

However, they believe that with many privileged Nigerians adopting this orientation, it can produce noticeable impact on the farmers. For example, one of the male participants who said "No" in the initial question noted "This may help in alleviating the plight of the rural farmers. However since it is not established, that is, this type of payment is like free will and at such is not regular and once not regular will not go a long way. Anybody who pays more today may not like to pay same tomorrow." Another said, "Yes, however, it would need many people doing so intentionally, otherwise, the effect may be rather low," (Female, below 50 years).

The participants identified various areas of vulnerability faced by smallholder rural farmers in Nigeria. The challenges identified include; inconsistent demand leading to product glut in some seasons, poor storage and food preservation facilities, inadequate feeding, wastages from delayed sales or unsold produce, loss from incidences arising from failed road network, destruction of produce by pests and plant diseases, underpricing of produce by middlemen, Poor sales, perished crops, erosion, poor crop yields, panic sales, and price takers position. These are in alignment 
with previous studies (Agu et al., 2017; Fidelugwuowo, et al., 2021; ILO, 2020; Obayelu et al., 2021; Ilesanmi et al., 2021).

Table 2: Marketing Professors' Responses to Specific Dichotomous Questions

\begin{tabular}{|c|c|c|}
\hline Questions/Options & Frequency & Percentage \\
\hline $\begin{array}{l}\text { Do you buy agricultural } \\
\text { produce directly from the real } \\
\text { (mainly rural) farmer? }\end{array}$ & & \\
\hline Yes & 19 & 100.00 \\
\hline No & 0 & 0.00 \\
\hline $\begin{array}{l}\text { Whether pre- or post-Covid- } \\
19 \text { pandemic, have you ever } \\
\text { paid a farmer more than the } \\
\text { asking price of his/her produce } \\
\text { or rendered support in any } \\
\text { form? }\end{array}$ & & \\
\hline Yes & 17 & 89.47 \\
\hline No & 2 & 10.53 \\
\hline $\begin{array}{l}\text { Given the impact of the } \\
\text { pandemic on low income } \\
\text { earners, if you have the } \\
\text { opportunity to buy from the } \\
\text { real rural farmer again, will } \\
\text { you consider to pay more to } \\
\text { help the farmer survive? }\end{array}$ & & \\
\hline
\end{tabular}




\begin{tabular}{|l|l|l|}
\hline Yes & 18 & 94.74 \\
No & 1 & 5.26 \\
\hline
\end{tabular}

Source: Interview Responses, 2021.

\section{Conclusion, Recommendations and Implications}

Findings from this study affirm that humane buying, if embraced by a good number of privileged individuals, can contribute in alleviating smallholder rural farmers' vulnerability, improve their livelihood and empower them for greater farming. However, to successful tackle the vulnerable situations of farmers, stakeholders - government, international agencies, institutions, privileged individuals, religious organizations among others, will require to provide adequate, affordable and modern farming input, security, education/training, good road network and efficient means of transportation to the vulnerable farmers. While these suggestions have in the past been left for the government and international agencies, this paper advocates for a shift to integrate larger stakeholders since the previous efforts have yielded little, given high level of corruption (Eranga, 2020; Ufua et al., 2021). Thus, humane (buying) orientation becomes imperative if we must actualize the SDGs by 2030. Therefore, stakeholders must be guided by ethical principles, morality and empathy in humanely supporting and empowering smallholder farmers to survive, and this will ensure food security altogether.

The present study makes some practical and theoretical contributions. Theoretically, the paper proposes, conceptualizes and validates humane buying as an exchange orientation/model that can help in actualizing the SDGs and ensuring food security post-Covid-19. It also extends our understanding of the theories of ethical consumption, sustainability, and helping behaviour (altruism) by linking them to the new concept - humane buying. Practically, the study outlines best approach to tackling smallholder rural farmers' vulnerability by proposing the humane stakeholders approach. Government and international organizations as well as other concerned bodies and individuals will find this study useful in moving the agricultural sector forward.

\section{Limitations and Areas for Future Research}


Being a new conceptualization, further research is expected that can provide more insights and validation. Specifically, future studies may explore scales development of humane buying and also use advanced analytical techniques to validate findings. The experimental scope could be enlarged to cover farmers from other parts of Nigeria.

\section{Declaration of Competing Interest: None.}

\section{Acknowledgements}

The first author is grateful to the 2019/2020 MSc Marketing set, at Abia State University, Uturu, Nigeria for their efforts in generating the experimental data. The professors of marketing who participated in the online/phone interview and the rural farmers that volunteered to participate are deeply appreciated. Members of the Track 9 of the 2021 The Academy of Management Nigeria (TAMN) conference, chaired by Professor Samila Mande and Dr. Doris Ademe-Godwin are acknowledged for their observations that have further strengthened this paper.

\section{References}

Agu, G.A. (2020). Perceived sales promotion transparency and customer intention to participate: Insight from student-bank customers in Nigeria. Journal of Marketing Communication, 27(7), 762-779.

Agu, G.A., Anyanwu, A,V., Okpara, G.S., Ogwo, E.O., \& Ibrahim, S. (2020). Consumption boycott as a remedy to herders-farmers rift in Nigeria: What factors drive consumers' willingness to participate? AMA's Marketing and Public Policy Conference, 30, 232.

Agu, G.A., Okpara, G.S., \& Benson-Eluwa, V. (2017). Promoting solutions to rural farmers' vulnerability in produce price negotiation in Nigeria: The role of marketing. Journal of Contemporary Marketing, 2(1), 65-84. 
Agu, G.A., Onwuka, O.O., Okocha, R., \& Madiche, N. (2021). Covid-19 pandemic and entrepreneurial intention among university students: the role of Igbo traditional business school. $4^{\text {th }}$ Chinua Achebe Conference, Institute of African Studies, University of Nigeria, Nsukka.

Beise-Zee R. (2013). Cause-Related Marketing. In: Idowu S.O., Capaldi N., Zu L., Gupta A.D. (eds) Encyclopedia of Corporate Social Responsibility. Springer, Berlin, Heidelberg. https://doi.org/10.1007/978-3-642-28036-8_551

Boitchi, A.B., Naher, Z., Pervez, S., \& Anama, M.M. (2021). Patient's understanding, management practices, and challenges regarding hypertension: A qualitative study among hypertensive women in a rural Bangladesh. Heliyon, 7(7), e07679.

Bright, M.P., Kudzai, N.T., \& Ngavatle, C. (2021). The impact of Covid-19 on agricultuaral extension and food systems in Zimbabwe. Cogent Food \& Agriculture, 7(1), 1918428.

Cerher, C., Altunkaynak, B., \& Guru, M. (2021). Impact of Covid-19 on agricultural product branches: an investigation of anxiety disorder among farmers. Sustainability, 13, 5786.

Chin, L. (1989). Morality and Economics. International Journal of Social Economics, 16(2), 312.

Cruz, B. P. A. (2017). The boycott intention analyzed from sexual orientation and religion. Amanque Inter-discipline Review, 1(1), 4 - 31.

Eranga, I. O. E. (2020). Covid-19 pandemic in Nigeria: Palliative measures and the politics of vulnerability. International Journal of Maternal and Child Health and AIDS, 9(2), 220.

Evans, C. (2017). Analyzing semi-structured interviews using thematic analysis: Exploring voluntary civil participation among adults. Sage Research Methods Datasets: Sage Publishing Ltd.

Ferraris, A., Giudice, M.D., Grandhi, B. \& Cillo, V. (2020). Refining the relation between causerelated marketing and consumers purchase intentions: A cross-country analysis. International Marketing Review, 37 (4), 651-669. https://doi.org/10.1108. 
Fideugwuowo, U.B. (2021). Knowledge and skills for accessing agricultural information by rural farmers in Southeast Nigeria. IFLA Journal, 47(2), 119-128.

Food and Agricultural Organization. (2021). National agrifood systems and Covid-19 in Nigeria: Effects, policy responses and long-term implications. www.fao.org.

Friets, R.L \& Vandermause, R. (2017). Data collection via in-depth email interviewing: Lessons from the field. Qualitative Health Research, 28(10), 1640-1649.

Gansonre, S. (2021). Welfare impacts of non-farm employed in semi-arid areas: Evidence from Burkina Faso. Heliyon, 7(10), e08080.

Ger, G. (1997). Human Development and Humane Consumption: Weil-Being beyond the "Good Life". Journal of Public Policy and Marketing, 16(1), 110-125.

Ilesanmi, F., Ilesanmi, O.S., \& Afolabi, A.A. (2021). The effect of Covid-19 pandemic on food losses in agricultural value chain in Africa: The Nigerian case study. Public Health in Practice, 2(100087).

International Labour Organization. (2020). Impact of Covid-19 on people's livelihoods, their health and our food system. www.ilo.org.

Kazeem, Y. (2020), “Here's how COVID-19 has battered Africa's largest economy”, Retrieved on $20^{\text {th }}$ February 2021, https://www.weforum.org/agenda/2020/08/africa-largest-economy-worstcontraction-in-a-decade/

Kim, K-C., El Tarabishy, A., and Bae, Z-T. (2018). Humane entrepreneurship: How focusing on people can drive a new era of wealth and quality job creation in a sustainable world. Journal of Small Business Management, 56(1), 10-29.

King, B. G. (2011). A political mediation model of corporate minority to social movement actualization. Adventure science quarterly, 53(3), 395 - 421.

Krebs, D.L. (1975) Empathy and altruism. Journal of Personality and Social Psychology, 32(6), 1134-1146. https://doi.org/10.1037/0022-3514.32.6.1134

Lavrakas, P.J. (2008). Census. In Encyclopedia of Survey Research Methods. Sage. 
Loftkowitz, J., \& Gebbia, M. (1997). The "shelflife" of a text validation study: a survey of expert opinion. Journal of Business and Psychology, 11(3), 381-397.

Macauley, J., \& Berkowitz, L. (1970). Altrusim and Helping Behaviour, New York: Academic Press.

Maricaci, T., Venuleo, C., Gunnaro, A., \& Sammut, G. (2021). Making sense of the COVID-19 pandemic: A qualitative longitudinal study investigating the first and second wave in Italy. Heliyon, 7(9), e07891.

Mehta, S., Saxena, T., \& Purohit, N. (2021). The new consumer behaviour paradigm amid Covid19: permanent or transient? Journal of Health Management, 22(2), 291-301.

Middendorf, B.J., Faye, A., Middendorf, G., Stewart, Z.P., Jha, P.K., \& Prasad, P.V. (2021). Smallholder farmer perception about the impact of Covid-19 on agriculture and livelihoods in Senegal. Agricultural Systems, 190, 103108.

Nchanji, E.B., \& Lutoma, c.k. (2021). Regional impact of Covid-19 on the production and food security of common bean smallholder farmers in Sub-Saharan Africa: Implications for SDGs. Global Food Security, 29, 100524.

Ndayo, N.U., Umoh, G.S., \& Ekpe, E.O. (2000). Framing systems in Southeast, Nigeria:

Implications for sustainable agricultural production. Journal of Sustainable Agriculture, 17(4), 75-89.

NUC. ( 2017). Directory of full professors in the Nigerian university system. www.nuc.edu.ng

Obayelu, A.E, Obayelu. A.O., \& Bolarinwa, K.K. (2021). Assesment of the immediate and potential effects of Covid-19 outbreak on socialeconomics, agriculture, security of food and dietary intake in Nigeria. Food Ethics, 6,5. https://doi.org/10.1007/s41055-021$\underline{00085}$.

OECD Policy Responses to Coronavirus (2020).Policy implications of Covid-19 crisis for rural development. www.oecd.org.

Omisore, S. (2019). Corporate Entrepreneurship, Strategy Formulation, and the Performance of the Nigerian Manufacturing Sector (Doctoral dissertation, University of East London). 
Ozili, P.K. (2020). Covid-19 pandemic and economic crisis: the Nigerian experience and structural causes. Journal of Economic and Administrative Sciences, doi/10:11088.

Parente, R. (2020). Digitalization, consumer social responsibility, and humane entrepreneurship: Good news from the future. Journal of the International Council for Small Business, 1(10), 56-63.

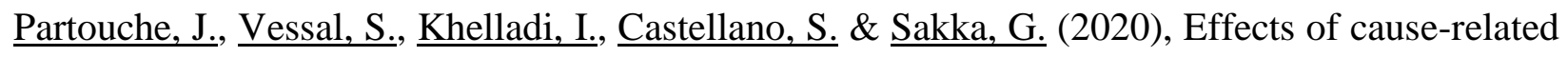
marketing campaigns on consumer purchase behavior among French millennials: A regulatory focus approach. International Marketing Review, 37 (5) 923-943.

Rushton, J.P (1982). Altruism and society: a social learning perspective. Ethics, 9,3, 425-446.

Smith, J.A., and Osborn, M. (2015). IPA as a useful methodology for research on the lived experience of pains. British Journal of Pain, 9(1), 41-42.

Sudbury-Riley, L., \& and Kohlbacher, F. (2016). Ethically minded consumer behavior: Scale review, development, and validation

The World Bank. (2020). Covid-19 to plunge global economy into worst recession since World War II.

The World Bank. (2021). The global economy: On track for strong but uneven growth as Covid19 still weighs.

Ufua, D.E., Osabuohien, E., \& Ogbari, M.E. (2021). Re-Strategizing government palliative support systems in tackling the challenges of Covid-19 lockdown in Lagos State, Nigeria. Glob Journal of Flexible System Management, 22, 19-32.

Wilson, D.W. (1978). Helping behaviour and physical attraction. The Journal of Social Psychology, 104(2), 313-314.

World Health Organization. (2020), “Coronavirus", www.who.int. 